\title{
Edukasi Pentingnya Melakukan Sortir Dalam Kegiatan Pemasaran Kentang Di Kecamatan Jangkat Kabupaten Merangin
}

\author{
Mirawati Yanita ${ }^{1)}$, Ardian Saputra1) \\ 1) Staf Pengajar Jurusan Agribisnis Fakultas Pertanian Universitas Jambi \\ Email: Mirawatiyanita@unja.ac.id
}

\begin{abstract}
Abstrak: Pengabdian masyarakat ini bertujuan untuk 1) Memberikan kontribusi yang berguna khususnya bagi petani yang terkait langsung maupun investor yang akan mengembangkan usaha berbahan baku kentang. 2) Meningkatkan minat petani komoditas kentang untuk meningkatkan produksi lebih banyak dan meningkatkan pertumbuhan ekonomi di Kecamatan Jangkat. 3) Menjadikan Kecamatan Jangkat contoh bagi petani di daerah yang lain bahkan dicontoh petani komoditas lainnya. Pengabdian ini dilaksanakan bulan Maret sampai Bulan Mei Tahun 2019. Penentuan lokasi pengabdian ini dilakukan secara sengaja (purposive) dengan pertimbangan Kecamatan Jangkat sebagai kecamatan penghasil kentang terbesar. Kegiatan pengabdian dimulai dari pemberian kuesioner awal tentang pentingnya melakukan sortir. Hal ini bertujuan untuk mengetahui sejauh mana pengetahuan petani mengenai apa itu sortir, bagaimana melakukan sortir yang benar, dan manfaat dari sortir itu sendiri. Pemberian sosialisasi tentang pentingnya sortir. hal ini bertujuan memberikan informasi mengenai sortir sehingga petani memahami pentingnya melakukan kegiatan sortir guna menarik petani untuk mempraktikkan langsung. Melakukan praktik langsung bersama petani pada saat panen raya. Hal ini bertujuan untuk mengawasi kegiatan sortir yang dilakukan petani agar mengetahui pemahaman petani dalam mempraktikkan sortir setelah mengikuti sosialisasi sebelumnya. Memberikan kuesioner akhir. Hal ini bertujuan untuk mengevaluasi kegiatan pengabdian dan mengetahui pemahaman petani serta pendapat petani bagaimana kegiatan sortir, apakah sortir perlu dilakukan dan dilanjutkan.
\end{abstract}

Kata Kunci : Kentang, Pengabdian, Sortir

\section{PENDAHULUAN}

Kentang dapat dijadikan sebagai komoditas hortikultura unggulan bagi Kecamatan Jangkat sehingga akan meningkatkan penghasilan petani kentang. Produksi yang besar belum bisa menghasilkan pendapatan daerah yang besar pula jika dalam kegiatan pemasarannya belum baik. Kentang yang telah di panen membutuhkan perlakuan pasca panen yang baik.

Penanganan pasca panen secara umum bertujuan untuk memperpanjang kesegaran dan menekan tingkat kehilangan hasil yang dilaksanakan melalui pemanfaatan sarana dan teknologi yang baik. Oleh karena itu, untuk mengurangi dampak teknologis, ekologis dan ekonomis diperlukan road map (peta perjalanan) penanganan pasca panen sebagai landasan dalam penyusunan program kegiatan, rencana aksi serta kebijakan (Dhalimi,1990).

Petani masih jarang melakukan kegiatan pasca panen yang baik, sehingga produk yang ingin dipasarkan tidak menarik bahkan kebanyakan rusak. Kegiatan pasca panen yang seharusnya dilakukan petani yaitu salah satunya kegiatan penyortiran kentang. Kentang yang sudah dipanen sebaiknya dilakukan sortir sehingga kentang yang buruk dapat dipisahkan, karena selama ini petani tidak melakukan kegiatan sortir yang akibatnya semua kentang yang rusak menjadi satu dengan kualitas yang baik, akhirnya pembeli merasa di rugikan.

Kegiatan pemasaran antara petani dan pembeli memiliki tujuan yaitu untuk mendapatkan kepuasan kedua pihak. Kepuasan yang diharapkan petani yaitu kentang dihargai dengan nilai yang tinggi sesuai dengan produk yang dijual, sedangkan pembeli mendapatkan kentang dengan kondisi yang baik dan berkualitas. Berdasarkan hal tersebut sehingga diperlukan 
edukasi yang baik bagi petani dalam melakukan kegiatan pasca panen untuk meningkatkan nilai jual kentang di pasar lokal maupun internasional.

Menurut Asmarantaka (2014) kegiatan pemasaran merupakan ujung tombak bagi pertanian sehingga hasil pertanian dapat tersampaikan ke konsumen. Kegiatan pemasaran yang baik adalah pemasaran yang bisa memberikan kepuasan seluruh pihak yang terlibat. Pihak yang terlibat terdiri dari produsen, penyalur hingga konsumen. Petani sebagai produsen hasil pertanian seharusnya menghasilkan produk yang memiliki kualitas yang baik, sehingga konsumen tertarik untuk membelinya.

Petani akan bersaing dengan petani yang lain dalam menjual produk yang sama, sehingga dibutuhkan peningkatan kualitas baik produk hingga kegiatan pemasarannya salah satunya adalah aktivitas pasca panen. Mengatasi permasalahan ini petani memerlukan informasi mengenai pentingnya memasarkan kentang dengan melakukan kegiatan sortir.

Tujuan dari penelitian ini adalah untuk mendorong petani dapat menawarkan kentang dengan varian harga berdasarkan kualitas atau ukuran komoditas kentang tersebut. Kentang dengan kondisi yang kurang baik tidak perlu khawatir tidak laku terjual. Kentang yang kurang baik dapat diolah menjadi produk turunan kentang seperti dodol dan lainnya, sehingga menimbulkan varian produk di Kecamatan Jangkat. Kondisi ini memerlukan kajian lebih lanjut untuk membantu petani mengatasi jatuhnya harga terutama pada saat panen raya.

Selain itu juga dapat mendorong petani melaksanakan kegiatan pasca panen secara sederhana tanpa perlu menunggu bantuan dari pemerintah untuk menambah pendapatan. Petani kentang di Kecamatan Jangkat sebagai salah satu penghasil kentang terbesar perlu diberikan pengetahuan berupa edukasi mengenai pentingnya melakukan sortir dalam memasarkan komoditas kentang. Kegiatan ini diharapkan akan memberikan peningkatan kualitas hidup petani dengan meningkatkan harga jual kentang akibat melakukan sortir.

Solusi yang diharapkan pada kegiatan pengabdian ini berupa :

1. Sosialisasi tentang kegiatan pasca panen yaitu sortir dapat disampaikan dan ditangkap petani sebagai bentuk kegiatan yang akan meningkatkan hasil pendapatan usaha tani kentang.

2. Kegiatan ini bukan sekedar memberikan informasi, melainkan juga pengawasan sehingga petani akan terus menerus melakukan sortir dalam kegiatan memasarkan kentang.

Adapun luaran yang dihasilkan dari solusi di atas adalah :

1. Memberikan kontribusi yang berguna khususnya bagi petani yang terkait langsung maupun investor yang akan mengembangkan usaha berbahan baku kentang.

2. Meningkatkan minat petani komoditas kentang untuk meningkatkan produksi lebih banyak dan meningkatkan pertumbuhan ekonomi di Kecamatan Jangkat.

3. Menjadikan Kecamatan Jangkat contoh bagi petani di daerah yang lain bahkan dicontoh petani komoditas lainnya.

\section{METODE KEGIATAN}

Lokasi dipilih secara purposive berdasarkan pertimbangan bahwa Kecamatan Jangkat merupakan salah satu daerah sentra penghasil kentang di Kabupaten Merangin. Pemilihan desa dengan karakteristik yang sama yaitu desa yang menghasilkan produksi kentang terbesar. Adapun objek penelitian ini adalah petani kentang yang melakukan kegiatan pemasaran 
kentang. Waktu kegiatan pengabdian ini akan dilakukan dimulai bulan Maret sampai Mei Tahun 2019.

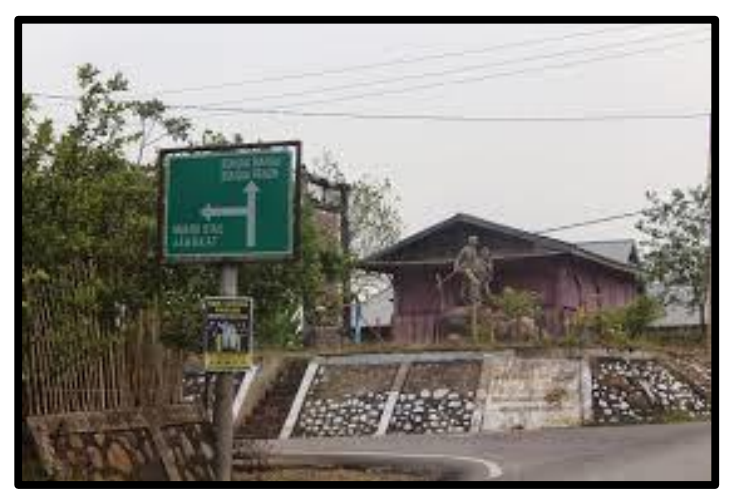

Gambar 1.

Lokasi kegiatan

Tahapan-tahapan dalam kegiatan penelitian ini adalah sebagai berikut:

1. Persiapan yang mencakup kegiatan yang terkait dengan koordinasi dan pembagian tugas, penyiapan instrumen penelitian seperti kuesioner dan materi edukasi.

2. Pelaksanaan yang mencakup:

a. Memberikan kuesioner awal mengenai melakukan kegiatan pasca panen berupa sortir

b. Memberikan edukasi tentang pentingnya melakukan sortir dalam kegiatan pemasaran melalui pemaparan presentasi.

c. Mempraktikkan secara langsung ketika panen raya.

d. Memberikan kuesioner akhir sebagai bahan evaluasi kegiatan.

3. Pelaporan yang mencakup penulisan jurnal publikasi dan penulisan laporan akhir.

\section{HASIL DAN PEMBAHASAN}

Pentingnya kegiatan edukasi ini pada masyarakat di Kecamatan Jangkat pada bulan Maret 2019 dan pengawasan dilakukan pada bulan Mei saat panen raya. Tahapan pada pelaksanaan kegiatan pengabdian ini yaitu:

\subsection{Pemberian kuesioner awal tentang pentingnya melakukan sortir.}

Pemberian kuesioner diberikan kepada masing-masing perwakilan kelompok tani di desa yang terdapat di Kecamatan Jangkat. Kuesioner disebar dan langsung dikumpulkan kembali setelah diisi semua peserta. Kemudian penyusun mengolah dan menyusun hasil dari kuesioner tersebut. Hal ini bertujuan untuk mengetahui sejauh mana pengetahuan petani mengenai apa itu sortir, bagaimana melakukan sortir yang benar, dan manfaat dari sortir itu sendiri. Keuntungannya dengan mengetahui sejauh mana pemahaman petani mengenai sortir akan lebih mudah menemukan materi yang tepat untuk petani dan akan lebih efektif dalam penyampaian materi. 


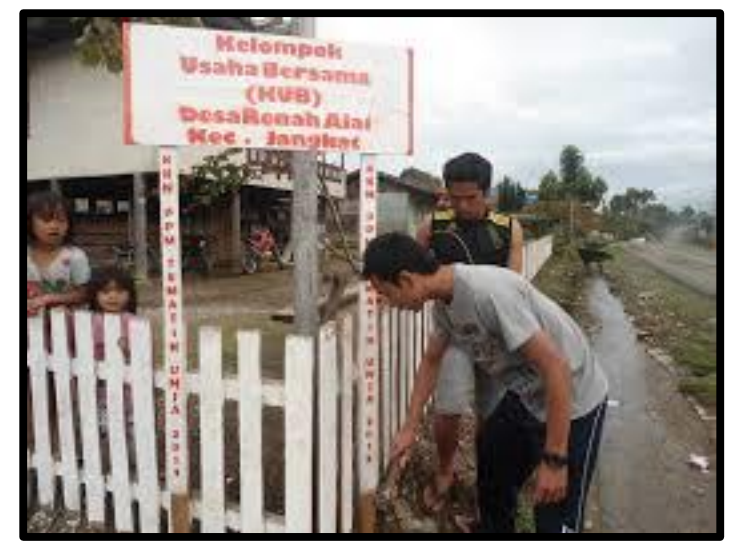

Gambar 2.

Lokasi Salah Satu Pemberian Kuesioner

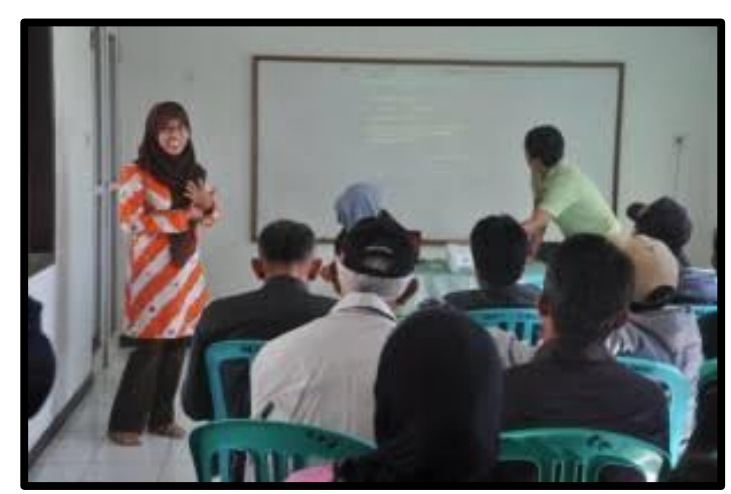

Gambar 3.

Pemberian Kuesioner Awal

\subsection{Pemberian edukasi tentang pentingnya sortir.}

Pemberian edukasi dilakukan di Aula Kecamatan Jangkat. Petani perwakilan desa diundang untuk hadir di Kecamatan dan mengikuti pemberian edukasi selama kurang lebih 2 jam dan dilanjutkan dengan sesi tanya jawab. Telah disepakati bersama metode pendekatan yang ditawarkan untuk memberikan edukasi melalui pemaparan presentasi dengan dikemas menarik agar petani dapat menerima dan memahaminya lebih mudah. Hal ini dimaksudkan agar pesan dari kegiatan ini dapat tersampaikan kepada petani dan petani mudah memahami materi edukasi. Isi dari edukasi ini bertujuan memberikan informasi mengenai sortir sehingga petani memahami pentingnya melakukan kegiatan sortir guna menarik petani untuk mempraktikkan langsung. Isi dari materi yang disampaikan selain sortir juga diberikan sosialisasi standar ukuran kentang yang baik dan memenuhi kriteria permintaan di pasar perusahaan. Hal ini yang menjadi acuan dalam melakukan sortir kentang yang akan dilaksanakan petani selanjutnya. Diberikan juga gambar-gambar yang menunjukkan standar dari kentang yang dikategorikan memiliki kualitas yang baik 


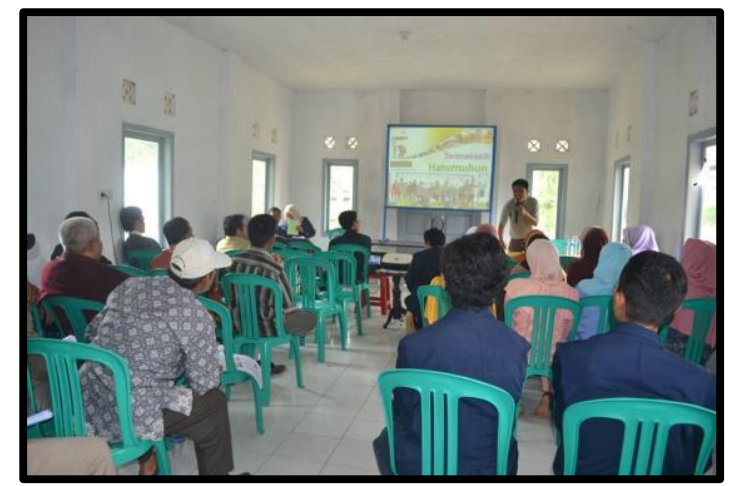

Gambar 4.

Pemberian Edukasi

\subsection{Melakukan praktik langsung bersama petani pada saat panen raya.}

Kegiatan praktik dilakukan ketika panen raya berlangsung. Setelah kegiatan panen petani diminta untuk melakukan sortir dengan diberikan wadah yang sudah memiliki label sesuai standar yang telah ditetapkan. Praktik ini juga diawasi dan memberikan contoh terlebih dahulu sebelum petani memulai mempraktikkannya sendiri. Hal ini bertujuan untuk mengawasi kegiatan sortir yang dilakukan petani agar mengetahui pemahaman petani dalam mempraktikkan sortir setelah mengikuti pemaparan edukasi sebelumnya. Kegiatan praktik langsung juga akan menambah wawasan petani mengenai sortir sesuai standar yang telah ditetapkan.

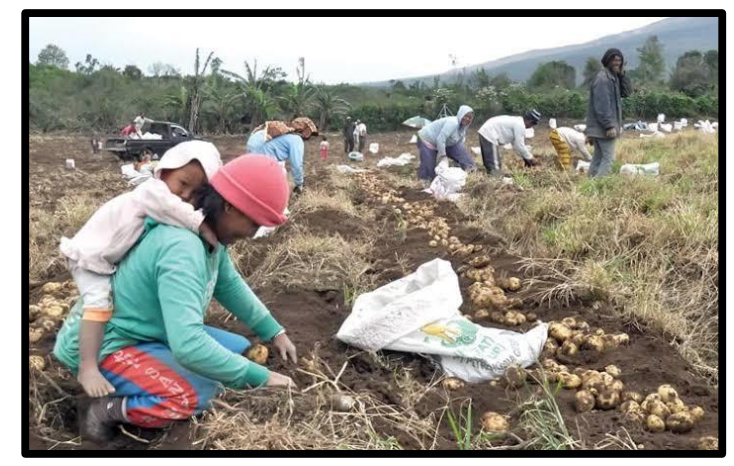

Gambar 5.

Panen Raya

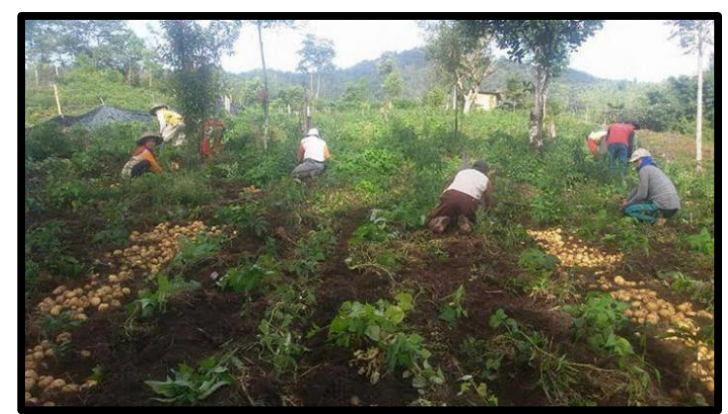

Gambar 6.

Praktik Sortir 


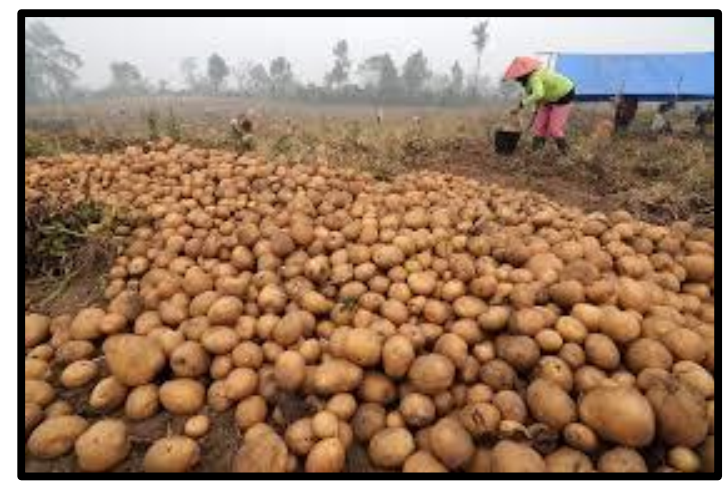

Gambar 7.

Kentang yang dipanen

\subsection{Memberikan kuesioner akhir.}

Memberikan kuesioner akhir dilakukan setelah melakukan praktik selesai. Petani dikumpulkan kembali dan diberikan kuesioner yang telah disiapkan sebelumnya. Setelah semua diisi dan dikumpulkan maka berakhirlah kegiatan pengabdian dan di akhiri dengan foto bersama. Hal ini bertujuan untuk mengevaluasi kegiatan pengabdian dan mengetahui pemahaman petani serta pendapat petani bagaimana respons dan pemahaman petani setelah diberikan edukasi dan praktik mengenai sortir.

Adapun langkah evaluasi pelaksanaan kegiatan ini dilaksanakan dengan membuat kuesioner pada saat sebelum dan sesudah kegiatan berlangsung. Hal ini untuk melihat sejauh mana respons dan pemahaman petani akan materi yang diberikan. Keberlanjutan program di lapangan setelah kegiatan pengabdian selesai dilaksanakan ditinjau secara berkala.

Diharapkan dengan adanya kegiatan pengabdian masyarakat ini dapat terjalin komunikasi timbal balik antara petani kentang Kecamatan Jangkat dengan tim pengusul kegiatan pengabdian masyarakat yang terarah pada pencapaian tujuan pemahaman. Diharapkan petani dapat melakukan dan melanjutkan kegiatan sortir pada masa mendatang sehingga investor tertarik untuk membantu mendistribusikan hasil kentang dengan kualitas yang bagus dan akan menambah pendapatan desa yang akhirnya Kecamatan Jangkat menjadi pusat agrowisata hortikultura khususnya komoditas kentang dan lainnya.

\section{KESIMPULAN}

Penelitian ini penting dilakukan karena dengan edukasi kepda petani kentang petani memahami manfaat dari kegiatan sortasi kentang dalam kegiatan pemasaran untuk memabantu meningkatkan pendapatan petai dengan kenaikan harga yang diterima dalam proses pemasaran dan distribusi kentang ke konsumen.

Keberlanjutan program di lapangan setelah kegiatan pengabdian selesai dilaksanakan ditinjau secara berkala. Diharapkan dengan adanya kegiatan pengabdian masyarakat ini dapat terjalin komunikasi timbal balik antara petani kentang Kecamatan Jangkat dengan tim pengusul kegiatan pengabdian masyarakat yang terarah pada pencapaian tujuan pemahaman. Diharapkan petani dapat melakukan dan melanjutkan kegiatan sortir seterusnya sehingga investor tertarik untuk mengambil hasil kentang dengan kualitas yang bagus dan akan menambah pendapatan desa yang akhirnya Kecamatan Jangkat menjadi pusat agrowisata kentang. 


\section{UCAPAN TERIMA KASIH}

Penulis mengucapkan terima kasih kepada Perangkat daerah di Kecamatan Jangkat yang telah memberikan bantuan dan dukungannya sehingga kegiatan ini dapat terlaksana dengan lancar.

\section{Referensi}

Asandhi, A.A. 2000. Analisis Finansial Budidaya Kentang di Dataran Medium pada Lahan Sawah. Jurnal Hortikultura, 10(2);154-164

Asmarantaka, Ratna W. 2014. Pemasaran Agribisnis (Agrimarketing). Penerbit IPB Press. Bogor.

Dhalimi, A. 1990., Penanganan Pasca Panen Buah-buahan dan Sayuran Segar. Makalah Pelatihan Kerja sama FAO - Dep. Perdagangan di Jakarta 12 - 14 Pebruari 1990, p. 17 37.

Hamid, Abdul K. 1972. Tataniaga Pertanian. IPB. Bogor. 